\title{
Peningkatan Kompetensi Guru PAUD Non Pg-PAUD Melalui Pendampingan Pembuatan Media Pembelajaran di Kecamatan Konda
}

\author{
Erdiyanti' ${ }^{1}$, Suhartini Syukri ${ }^{2}$ \\ 1,2Institut Agama Islam Negeri Kendari \\ e-mail : erdiyantierdi@gmail.com ${ }^{1}$, suhartinisyukri@gmail.com²
}

\begin{abstract}
ABSTRAK. Penelitian ini merupakan penelitian Participatory Action Research (PAR) yang dilakukan dalam bentuk pendampingan guru PAUD non-PG PAUD di desa se-kecamatan Konda, Kabupaten Konawe Selatan, Kendari, Indonesia. Tujuan penelitian ini adalah untuk menggali data kemampuan guru PAUD non-PG PAUD dalam mendesain dan membuat media pembelajaran sederhana bahasa Inggris serta untuk mengetahui sejauh mana melalui pelatihan pendampingan tersebut dapat meningkatkan kompetensi pedagogis dan profesional guru PAUD non-PG PAUD di desa se-kecamatan Konda. Teknik pengumpulan data yang dilakukan berupa studi pustaka mengenai informasi teoretik dan penelitian yang relevan; In-depth Interview (wawancara mendalam); observasi dan dokumentasi. Kerangka PAR yang digunakan adalah diagnosa (persiapan dan perencanaan), tindakan, evaluasi dan refleksi. Hasil penelitian ini memperlihatkan bahwa kemampuan guru PAUD non-PG PAUD dalam mendesain media pembelajaran masih rendah sebab masih kurang pelatihan dan referensi, dalam hal pembuatan, semangat dan ketekunan sudah mulai nampak hanya sebagian besar masih mengikuti contoh dari hasil penelitian, serta hasil evaluasi akhir, pelatihan ini dapat meningkatkan kompetensi pedagogis dan profesional guru PAUD non-PG PAUD di desa seKecamatan Konda terlihat dari observasi dan refleksi akhir peneliti pada TK dan PAUD desa dampingan di Kecamatan Konda.
\end{abstract}

Kata Kunci : Guru PAUD non-PG PAUD, Kompetensi Pedagogis, Kompetensi Profesional, Media Pembelajaran.

ABSTRACT. This study is a Participatory Action Research (PAR) study conducted in the form of mentoring PAUD non-PG PAUD teachers in villages of Konda sub-district, Konawe Selatan District, Kendari, Indonesia. The purpose of this study was to explore data on the ability of PAUD non-PG PAUD teachers in designing and creating English learning media and to find out how far through the mentoring training can improve the pedagogical and professional competence of PAUD non-PG PAUD teachers in villages in the Konda sub-district. Data collection techniques are carried out in the form of literature studies on relevant theoretical information and research; In-depth interview; observation and documentation. The PAR frameworks used are diagnosis (preparing and planning), action, evaluation and reflection. The results of this study indicate that the ability of PAUD non-PG PAUD teachers in designing instructional media is still low since there is still lack of training and references. Besides, in terms of making product of learning media, teachers' enthusiasm and perseverance, they have begun to create the media. Nevertheless, most of teachers still followed the models given in mentoring process. Moreover, the results in final evaluation step of PAR, this training can improve the pedagogical and professional competence of PAUD non-PG PAUD teachers in Konda villages as what obviously occurred based on the observation results and final reflection of researchers in the kindergarten and PAUD of Konda district

Keyword : Non-PG PAUD teachers, Pedagogical Competence, Professional Competense, Learning Media. 


\section{PENDAHULUAN}

Pendidikan sebagai upaya pengembangan seluruh potensi anak agar dapat berkembang optimal membutuhkan tenaga pendidik anak usia dini yang profesional. Peraturan pemerintah (PP) nomor 19 tahun 2005 tentang standar pendidik dan tenaga kependidikan, menyatakan bahwa pendidik harus memiliki kualifikasi akademik dan kompetensi sebagai agen pembelajaran, sehat jasmani dan rohani serta memiliki kemampuan untuk mewujudkan tujuan pendidikan nasional. Kualifikasi akademik tersebut adalah tingkat pendidikan minimal (D-IV atau S1) dengan latar belakang pendidikan tinggi bidang pendidikan anak usia dini, kependidikan lain atau psikologi dan memiliki sertifikat pendidik PAUD. Kesesuaian kualifikasi pendidikan yang telah ditempuh akan menunjang keberhasilan guru dalam menjalankan tugas yang diembannya.

Mengingat bahwa salah satu faktor utama penentu kualitas pendidikan adalah tenaga pendidik, maka guru selaku tenaga pendidik merupakan titik sentral pendidikan[1]. Guru sebagai ujung tombak dituntut untuk dapat menyelenggarakan proses pembelajaran yang berkualitas. Hal tersebut sebagaimana tercantum dalam PP tahun 2005 tentang Standar Nasional Pendidikan Pasal 1.1 yang menegaskan bahwa kedudukan guru sebagai tenaga profesional khususnya pada jalur formal pada jenjang pendidikan anak usia dini memegang peran yang sangat menentukan dalam membentuk sumber daya manusia Indonesia yang berkualitas sejak anak usia dini.

Namun realitasnya, masih ada sebagian guru PAUD justru hanya tamatan SMA atau sarjana dengan kualifikasi akademik non PG-PAUD. Observasi awal peneliti pada 21 PAUD se-kecamatan Konda, Konawe Selatan Sulawesi Tenggara, menunjukkan bahwa hampir sebagian besar PAUD memiliki guru berkualifikasi tamatan SMA dan non PG-PAUD. Guru PAUD mereka mengalami kesulitan dalam melaksanakan proses pembelajaran disebabkan masih minimnya pengetahuan terkait bagaimana membuat perencanaan pembelajaran, melaksanakan proses pembelajaran hingga mengevaluasi proses pembelajaran di PAUD yang tentunya membutuhkan pengetahuan dan ketrampilan khusus.

Wawancara awal dengan salah satu Kepala TK di Kecamatan Konda menyatakan, dari 30 anak didik di TK tersebut, hanya memiliki 4 orang guru dan tidak seorangpun yang berkualifikasi PG-PAUD dengan 2 guru hanyalah tamatan SMA, sehingga kebutuhan akan pelatihan sangatlah diperlukan. Kondisi guru di RA tersebut tidak berbeda jauh dengan kondisi umum guru PAUD yang ada di Kecamatan Konda Kabupaten Konawe Selatan. Data awal yang diperoleh menunjukkan bahwa dari delapan Desa yang tersebar di Kecamatan Konda hanya 5 desa yang sudah memiliki PAUD dan 3 desa belum ada. Sedangkan, guru PAUD yang terdapat di 5 Desa tersebut belum ada satu pun guru PAUD yang berkualifikasi S1 PAUD, bahkan sebagian hanya tamatan SMA.

Selain terkait kualifikasi guru PAUD, pengajaran di dunia anak memerlukan kontribusi berupa inovasi, kreativitas serta ilmu yang berkelanjutan dengan disokong sarana dan prasarana yang mendukung keberhasilan pembelajaran di sekolah khususnya pada Pendidikan Anak Usia Dini (PAUD). Dalam hal ini, kompetensi yang baik dari guru ataupun pendidik di sekolah mengejawantahkan pentingnya hal ini dijadikan perhatian besar dalam dunia pendidikan. Hasil observasi awal, selain terkait dengan kompetensi guru yang lebih banyak tidak berasal dari latar belakang pendidikan yang sesuai, penggunaan media termasuk display dan pembuatannya oleh guru PAUD nampaknya masih sangat minim. Hal tersebut terlihat pada awal observasi kelas yang masih kurang dalam hal media pembelajaran. Selain faktor dana yang 
kurang, referensi pun menjadi salah satu alasan dan juga bahwa diakui pengalaman pendidikan kurang mendukung kreativitas guru. Berdasarkan simpulan wawancara awal, mereka berpendapat bahwa untuk menghasilkan media yang baik, pastilah membutuhkan dana yang banyak dan waktu yang tergerus, sehingga minimnya media dianggap cukup akan tetapi menjadikan suasana kelas gersang dengan inovasi pendidikan dan display menarik layaknya tempat belajar untuk anak usia dini. Lagipula, lanjut mereka, bahwa sekolah di PAUD pada remote area (desa ataupun tempat terpencil), dengan media sederhana dan seadanya sudah cukup meski memang dianggap kurang. Hal ini menjadi catatan besar bagi peneliti sejak mendapatkan data awal observasi pada penelitian ini.

Media pembelajaran sederhana berbahasa Inggris telah banyak dilakukan oleh peneliti sebelumnya yang dijabarkan pada penelitian relevan. Namun yang menjadi titik tolak terbesar adalah, media yang baik adalah media yang secara kelayakan memenuhi syarat, juga tidak mengerus biaya banyak, serta membutuhkan andil banyak dari guru PAUD itu sendiri, serta sesuai dengan kebutuhan anak usia dini berdasarkan umurnya. Pada penelitian ini, tantangan tersebut menjadi fokus penelitian yang mengacu kepada pembuatan media ajar yang mudah, kreatif, menarik dan yang terpenting adalah sederhana tetapi tetap istimewa.

Selain itu, penelitian mengenai pembuatan media untuk guru PAUD seringkali dilakukan, misalnya penelitian pembuatan media pembelajaran Big book guru-guru TK/PAUD di Madiun[2], pembuatan media dengan bahan sisa [3], serta pembuatan media berbasis IT misalnya dengan PPT[4]. Meskipun penelitian terkait dengan kompetensi guru PAUD dan pembuatan media pada guru PAUD di berbagai wilayah di Indonesia telah banyak dilakukan, namun masih jarang yang fokus kepada kompetensi guru Non PG-PAUD. Berdasarkan fenomena tersebut, penelitian ini mengulik informasi mengenai kemampuan guru PAUD non-PG PAUD dalam mendesain media pembelajaran, membuat media pembelajaran dan Sejauhmana melalui pendampingan pembuatan media pembelajaran dapat meningkatkan kompetensi guru PAUD non-PG PAUD. Hal tersebut menjadi penting untuk memfasilitasi guru PAUD Non PG-PAUD se-kecamatan Konda Kabupaten Konawe Selatan melalui serangkaian kegiatan yang dikemas dalam satu paket pengabdiaan, dengan fokus utama; workshop pelatihan pembuatan media pembelajaran sebagai implementasi pembelajaran Kurikulum 2013 di PAUD.

Terdapat empat kompetensi yang perlu dimiliki oleh guru PAUD, diantaranya: (1) Kompetensi pedagogik, yaitu berkaitan dengan kemampuan guru untuk memahami anak didik, menjadi teladan bagi anak, menginternalisasikan nilai dalam tindakan dan menjadikan kasih sayang sebagai dasar dalam mendidik; (2) Kompetensi kepribadian, yaitu berkaitan dengan kemampuan guru untuk menampilkan dirinya secara utuh, diantaranya responsif, komunikatif, peduli, menghargai anak, sabar, humoris, bertanggung jawab; (3) Kompetensi sosial, yaitu berkaitan dengan kemampuan memahami anak dalam konteks sosial-budaya dan mampu bekerja sama dengan lingkungan sosial, misalnya mampu menjalin kerjasama yang baik dengan anak, orang tua, rekan kerja, dsb, serta melibatkan keluarga dan masyarakat dalam pendidikan anak. (4) Kompetensi professional, yaitu berkaitan dengan pengetahuan, keterampilan dan sikap yang harus ditampilkan guru dalam melaksanakan tugasnya secara professional, misalnya memahami karakteristik, kebutuhan dan perkembangan anak didik, merencanakan dan melaksanakan kurikulum, melaksanakan berbagai pendekatan pembelajaran yang mendukung dan melakukan penilaian[5]. Pada penelitian ini, peneliti mengerucutkan penjabaran jenis kompetensi guru PAUD pada kompetensi pedagogik dan kompetensi profesional. 


\section{Kompetensi Pedagogik Guru PAUD}

Kompetensi pada dasarnya merupakan kemampuan atau kecakapan. Kompetensi merupakan peleburan kecakapan, kemahiran, pengetahuan serta kinerja untuk mencapai tujuan pekerjaan berdasarkan kondisi syarat yang diharapkan [6]. Dalam penelitian ini, kompetensi yang dimaksud merujuk kepada kemampuan pedagogis seorang guru PAUD. Keilmuan pedagogik mengkaji langkah membimbing anak, tugas pendidik, tujaun mendidik, dan bagaimana sebaiknya guru harus menguasai ilmu PAUD. Proses pedagogis sebagai sebuah proses pendidikan yang menyoroti hubungan antara pendidikan, pengajaran dan pembelajaran yang bertujuan agar siswa dapat mempersiapkan diri menyiapkan kehidupan[1]. Ini merupakan life skill yang dipercaya menjadi pembentukan awal sebuah pendidikan dasar yang diberlakukan sejak dini sebagai tujuan jangka panjang. Indikator kompetensi pedagogik guru secara lebih rinci mengacu kepada Peraturan Menteri Pendidikan Nasional (Permendiknas) Nomor 16 Tahun 2007.

Memahami karakteristik peserta didik anak usia dini yang berhubungan dengan aspek fisik, intelektual, sosio-emosional, moral, dan latar belakang sosialbudaya, moral, dan latar belakang sosial-budaya. Sebagai penyokong indikator di atas, terdapat sekolah berbasis multiple intelegences[7]. Pada sekolah jenis ini, kompetensi pedagogik seorang pendidik PAUD hendaknya menjadikan guru kreatif, terus mau belajar dan mencipta. Elaborasi yang bisa ditawarkan berupa bagaimana mendeteksi gaya belajar, mengenali dan melejitkan kecerdasan setiap anak, memudahkan pembelajaran, mengubah siswa "bermasalah" menjadi berpotensi serta memperkaya orang tua dan penggiat pendidikan[1]. Hal tersebut pada pemaparan di atas menjadi bekal dasar bagi pendidik PAUD meningkatkan kompetensi pedagogis dalam pengajarannya.

\section{Kompetensi Profesional Guru PAUD}

Pentingnya PAUD menuntut pendidik PAUD untuk menjadi seseorang yang profesional. Profesional berarti bekerja sesuai prosedur, mengikuti etika profesi dan ilmu PAUD, serta tidak melakukan kesalahan[8]. Selain itu, Driscoll dan Nagel[9] menyatakan bahwa "a professional is someone who is educated, knowledgable, dedicated to her profession, commited to completion of a specialized course of study, and in possession of a knowledge base essential to her speciality area". Professional dalam hal ini seseorang yang berpendidikan, berdedikasi terhadap pekerjaannya, dan memiliki kemampuan dasar sesuai dengan profesinya.

Nomenklatur profesionalisme menjadi hal yang sudah tidak asing bagi pegiat pendidikan. Akan tetapi, kompetensi yang menjadi syarat utama seorang pendidik ini membutukhan awareness (kesadaran) utuh hingga dapat menjadi kebiasaan serta tabiat baik bagi seorang pendidik, utamanya mereka yang mengusung tujuan pendidikan nasional untuk mencerdaskan anak bangsa sejak usia dini. Menilik hal tersebut, Pidarta [10] menyebutkan ciri-ciri professional bagi seorang guru yaitu sebagai berikut: 1. bekerja sepenuhnya dalam jam-jam kerja, 2. pilihan pekerjaan yang didasari dengan motivasi yang kuat, 3. memiliki seperangkat pengetahuan, ilmu dan keterampilan khusus yang diperoleh dari pendidikan dan latihan yang lama, 4. mampu memiliki keputusan sendiri dalam menyelesaikan pekerjaan, 5. pekerjaan berorientasi kepada pelayanan, bukan untuk kepentingan pribadi, 6. pelayanan dilakukan untuk kebutuhan objektif klien (dalam hal ini peserta didik), 7. memiliki otonomi untuk bertindak dalam menyelesaikan persoalan klien, 8. menjadi anggota organisasi profesi, memenuhi persyaratan tertentu, 9. memiliki kekuatan dan status 
yang tinggi sebagai ahli dalam spesialisasinya, dan 10. keahlian ini tidak boleh diadvertensikan untuk mencari klien.

Dengan versi lainnya, profesi pendidikan di Amerika Serikat, menyajikan karakteristik, sebagai berikut: 1). pekerja jasa social yang unik, jelas dan penting, 2) menekankan tekhnik intelektual 3) membutuhkan pendidikan spesialisasi dalam waktu panjang 4) memerlukan otonomi yang luas sebagai individu ataupun organisasi profesi, 5) otonomi individu mendapatkan persetujuan dari organisasi profesi, 6) tekanan pada jasa lebih besar dibandingkan dengan hasil ekonomis, baik secara perorangan maupunsecara kelompok professional, 7) memiliki organisasi profesi secara otonom dan 8) kode etik yang jelas dan tegas [10].

Selain itu, beberapa hasil studi profesionalisme menitiberatkan profesionalisme dalam hal yang terkait dengan bagaimana kemampuan untuk memahami tahapan perkembangan anak, pertumbuhan dan perkembangan anak, kemampuan untuk memberikan ransangan pendidikan, pengasuhan dan perlindungan serta kerjasama dengan orang tua dan masyarakat dalam hal pendidikan, pengasuhan dan perlindungan. Berdasarkan acuan teori di atas, peneliti menarik kesimpulan sederhana, bahwa profesionalisme merupakan kompetesi utama seorang guru yang menitikberatkan kepada pelayanan maksimal seorang guru sebagai praktisi pendidikan kepada peserta didik dengan kemampuan terbaiknya.

\section{Media Pembelajaran di PAUD}

Secara umum, media merupakan perantara atau pengantar pesan dari pengirim pesan ke penerima pesan sehingga dapat merangsang pikiran, perasaan dan perhatian anak didik untuk tercapainya tujuan pendidikan [11]. Media pengajaran dibagi dua bagian yaitu media dalam arti sempit dan media dalam arti luas [12]. Dalam arti sempit, media pengajaran hanya meliputi media yang dapat digunakan secara efektif dalam proses pengajaran yang terencana, sedangkan dalam arti luas, media tidak hanya meliputi media komunikasi elektronik yang kompleks akan tetapi juga mencakup alatalat sederhana seperti slide, fotogarfi, diagram dan bagan buatan guru. Media yang biasa digunakan pada pendidikan anak usia dini adalah media yang dibuat sendiri oleh guru atau media imitasi yang dibeli namun harus sesuai dengan tema yang ada pada rancangan kegiatan mingguan (RKM) dan rancangan kegiatan harian (RKH) hari itu [4]. Dalam hal ini, dibutuhkan tingkat kreativitas guru dihubungkan dengan materi dan rancangan kegiatan yang telah disusun dalam RKM dan RKH. Dalam rangka upaya peningkatan mutu proses kegiatan belajar-mengajar pada PAUD, perlu diperhatikan bebrapa prinsip-prinsip dalam penggunaanya antara lain: 1. Media pembelajaran yang dibuat hendaknya dapat digunakan untuk mengembangkan berbagai aspek perkembangan anak dan dapat dijadikan sebagai media pembelajaran secara berulang dengan tema dan sub tema yang berbeda. 2. Bahan mudah didapat di lingkungan sekitar lembaga PAUD dan murah atau bisa dibuat dari bahan bekas ataupun sisa[4]. Senada dengan hal ini, membuat media pembelajaran tidak harus selalu dengan biaya yang mahal, sebab banyak bahan-bahan sekitar yang dapat digunakan untuk membuatnya.

Manfaat media pembelajaran secara umum, adalah adalah memperlancar interaksi antara guru dengan anak sehingga kegiatan pembelajaran lebih efektif dan efisien. Sedangkan secara khusus, menurut Hamalik[13], manfaat media pembelajaran adalah: 1) menyeragamkan penyampaian materi pembelajaran, 2) Proses pembelajaran menjadi lebih jelas dan menarik, 3) Proses pembelajaran menjadi lebih interaktif, 4) Dengan media tujuan belajar akan lebih mudah tercapai secara maksimal dengan waktu dan tenaga seminimal mungkin, 5) Meningkatkan kualitas hasil belajar anak, 6) Media 
memungkinkan proses belajar dapat dilakukan di mana saja dan kapan saja, 7) Media dapat menumbuhkan sikap positif anak terhadap materi dan proses belajar, 8) Mengubah peran guru kearah yang lebih positif dan produktif. Media pembelajaran untuk anak usia dini bukan hanya media yang sengaja dirancang dan didesain oleh guru akan tetapi benda apapun bisa dijadikan media pembelajaran selagi benda itu memiliki nilai edukasi serta kebermanfaatan yang baik.

Media pembelajaran adalah media atau alat yang menjadi perantara dalam menyampaikan pembelajaran pada anak usia dini karena anak usia dini tidak bisa lepas dari media pembelajaran namun prinsipnya alat yang digunakan sebagai media pembelajaran tersebut harus mampu menstimulasi semua aspek perkembangan anak dan mampu mengatasi rasa bosan pada anak sehingga pembelajaran berjalan dengan efektif. Adapun jenis media dalam kegiatan bermain sambil belajar pada anak Taman Kanak-kanak, antara lain: a. Media audio atau media dengar yang dapat menyampaikan pesan melalui suara dan bunyi seperti suara bahasa, musik, dan sound effect dapat dikombinasikan untuk menguatkan isi pesan. b. Media visual yaitu media yang dapat digunakan untuk menyampaikan pesan/informasi melalui penglihatan yang berbentuk simbol-simbol visual, dan c. Media audio visual yaitu media yang dapat menyampaikan pesan menyatukan audio dan visual melalui suara, gambar, dan tulisan[14]. Guru-guru dapat berlatih lagi secara mandiri melalui modul pembuatan video pembelajaran "Kinemaster" yang sudah diberikan. Selain itu, guru-guru dapat mebuat rekaman video menggunakan green screen yang telah diberikan dengan lebih kreatif lagi[15].

Proses dan hasil belajar anak usia dini menunjukkan perbedaan yang berarti antara pengajaran tanpa media dengan pembelajaran menggunakan media. Secara umum, kedudukan media pengajaran ada dalam komponen metode mengajar sebagai salah satu upaya mempertinggi proses interaksi guru siswa dan interaksi siswa dengan lingkungan belajarnya. Melalui penggunaan media pengajaran, diharapkan dapat mempertinggi kualitas proses belajar-mengajar yang pada akhirnya dapat memengaruhi hasil belajar.

\section{METODE}

Penelitian ini menggunakan Participatory Action Reasearch (PAR). Adapun populasi sekaligus menjadi sampel keseluruhan penelitian ini adalah guru PAUD non PG-PAUD dari 5 desa se-Kecamatan Konda, Konawe Selatan. Adapun tenaga pendidik pada tiap desa berbeda-beda berjumlah 10 orang; 2 orang S1, non PG-PAUD, serta 8 guru kualifikasi akademik SMA dan yang sederajat. PAR ditujukan untuk melakukan perbaikan dan peningkatan kualitas guru non PG-PAUD dengan pelibatan guru sebagai mitra partisipatif.

Teknik pengumpulan data berupa studi pustaka mengenai informasi teoretik dan penelitian yang relevan; In-depth Interview (wawancara mendalam); observasi dan dokumentasi. Hal ini dilakukan untuk mengetahui hasil workshop dan pengaplikasiannya di sekolah. Kerangka PAR yang digunakan berupa: 1.) Diagnosa (Diagnosing) dengan melakukan identifikasi masalah terkait dengan kendala guru selama mengajar. Pada bagian ini, terdiri dari persiapan dan perencanaan. Langkah yang ditempuh adalah melakukan wawancara kepada stakeholder atau pihak sekolah ataupun guru yang terkait langsung maupun tidak langsung sebagai poin penting acuan dasar pada penelitian. Peneliti mengidentikasi kebutuhan dan langkah apa yang 
kemudian akan diambil. Observasi kelas juga menjadi bahan penguat mengenai kompetensi pedagogis dan professional guru PAUD non PG-PAUD yang akan ditindaklajuti pada tahapan berikutnya. Selanjutnya, 2) peneliti membuat rencana tindakan (Action Planning). Pada tahap ini, peneliti menganalisis pokok masalah dengan menyusun rencana tindakan yang tepat sebagai treatment pada masalah yang ditemukan di lapangan. Peneliti kemudian membuat desain workshop terkait dengan peningkatan kompetensi dan professional guru PAUD. Workshop dilakukan satu kali dalam beberapa hari yaitu melakukan 3) tindakan (action taking). Pada bagian ini, peneliti bersama-sama pihak terkait, serta guru PAUD akan melakukan berupa workshop pembuatan media pembelajaran guru PAUD non-PG PAUD, yang kemudian akan dilanjutkan dengan melakukan 4) implementasi, evaluasi dan 5) refleksi hasil workshop. Pada bagian akhir, peneliti merangkum seluruh hasil penelitian dalam bentuk laporan penelitian.

Peserta pelatihan terdiri dari 10 orang peserta maka guru yang berpendidikan SMA ada 8 orang dan 2 orang guru sarjana dari non PG-PAUD. Dibatasinya jumlah peserta dalam kegiatan pelatihan ini dimaksudkan untuk memaksimalkan kegiatan pendampingan yang dilakukan sehingga kedepan diharapkan guru TK/PAUD non PGPAUD yang telah berhasil dalam mengikuti pelatihan pembuatan media pembelajaran PAUD dapat membagi ilmu yang didapatkan selama mengikuti pelatihan kepada guru PAUD yang lain.

\section{HASIL DAN PEMBAHASAN}

\section{Pemberdayaan Guru PAUD Non PG-PAUD di Kecamatan Konda Persiapan (Diagnosa)}

Pada Siklus 1, Kegiatan awal yang dilakukan tim peneliti dalam rangka pemberdayaan guru PAUD Non PG-PAUD adalah sosialisasi kepada para guru PAUD Non PG-PAUD di Kecamatan Konda. Dalam sosialisasi tersebut awalnya peneliti melakukan pertemuan dengan beberapa kepala TK/PAUD, dan para guru PAUD Non PG-PAUD yang menjadi fokus pemberdayaan, serta pemateri kegiatan pelatihan. Dari pertemuan tersebut terungkap bahwa salah satu kendala yang menyebabkan proses pembelajaran belum dapat berjalan efektif karena para guru PAUD Non PG-PAUD di Kecamatan Konda belum pernah diberikan pelatihan terutama tentang pembuatan media pembelajaran PAUD.

Selama ini, guru PAUD Non PG-PAUD hanya membuat dan menggunakan media pembelajaran berdasarkan pengetahuan yang diperoleh dari sesama guru dan bukan dari tenaga profesional dalam hal ini sarjana PAUD, dan para guru kesulitan dalam hal pembuatan media yang berdampak pada kualitas dan kompetensinya menjadi guru yang profesional, kreatif dan inovatif, disebabkan oleh kekurangan referensi dan dana dalam membuat media pembelajaran. Berdasarkan hasil wawancara dengan salah satu Kepala TK, hal-hal yang urgen untuk dilakukan dalam kegiatan program pemberdayaan yaitu bahwa guru PAUD Non PG-PAUD saat ini membutuhkan bimbingan dan arahan tentang bagaimana mendesain dan membuat media pembelajaran di PAUD yang dapat mengembangkan berbagai aspek perkembangan siswa.

\section{Perencanaan}

Penyusunan draft program kegiatan kemudian dilakukan dalam bentuk FGD (Focus Group Discussion) dengan mengundang ahli (guru PAUD berlatar belakang PG- 
PAUD, yang memiliki pengalaman di bidang kePAUDan), dan juga mendiskusikannya bersama guru-guru PAUD se-kecamatan Konda Kabupaten Konawe Selatan. Kegiatan ini dilakukan selama sehari yang selanjutnya akan dieksekusi pada kegiatan workshop pendampingan guru PAUD berlatar belakang pendidikan non-PG PAUD dalam rangka pembuatan media ajar berbahan sederhana dan bersifat mudah serta praktis.

\section{Tindakan}

Pada tahapan tindakan, kegiatan peningkatan kompetensi guru PAUD Non PG- PAUD melalui Pelatihan Pembuatan Media Pembelajaran PAUD di Kecamatan Konda diikuti oleh 10 orang peserta yang merupakan guru yang berasal dari lima PAUD/TK yang tersebar di lima desa. Tema pelatihan adalah "Media Pembelajaran Sederhana di PAUD dari Bahan bekas. Berdasarkan Tema Pelatihan, maka pembuatan Media Pembelajaran Sederhana di PAUD berupa pembuatan Media Kotak Huruf, Angka dan Ular Tangga Pintar selama 2 hari. Peserta pelatihan memperlihatkan respon positif dan reaksi kreatif yaitu nampak serius, antusias dan bekerja sama berdasarkan hasil pembuatan media selama pelaksanaan kegiatan workshop

\section{Evaluasi}

Evaluasi pelaksanaan program pelatihan dilakukan selama proses kegiatan berlangsung, sejak dari awal hingga seluruh rangkaian kegiatan selesai dilaksanakan meliputi kegiatan pemberian materi tentang pembuatan media pembelajaran Huruf dan Angka serta Ular Tangga Pintar yang dilanjutkan dengan Praktik oleh seluruh peserta. Berdasarkan hasil pengamatan selama kegiatan pelatihan menunjukkan bahwa : a) Seluruh peserta aktif dalam menyimak materi-materi yang disampaikan oleh pemateri dan memberi respon yang baik, hal ini ditunjukkan dengan antusias para peserta pelatihan mengajukan pertanyaan-pertanyaan yang menjadikan situasi hangat dan komunikatif, dan seluruh acara yang direncanakan berlangsung dengan lancar serta berlangsung sesuai dengan target yang diharapkan; b) Keseriusan seluruh peserta ditunjukkan pada saat praktik pembuatan media semuanya terlibat secara aktif membuat dan bekerjasama dengan tim masingmasing kelompok untuk menghasilkan media yang semenarik mungkin; dan c) Kedisiplinan peserta selama mengikuti pelatihan ditunjukkan dengan kehadiran tepat waktu selama dua hari berturut-turut sesuai jadwal yang dibuat oleh tim peneliti mulai dari acara pembukaan kegiatan pelatihan sampai kegiatan pelatihan berakhir mencapai seratus persen.

\section{Refleksi}

Pada tahap ini tim peneliti melakukan Focus Group Discussion (FGD) untuk mengkaji rangkaian tahapan kegiatan pelatihan. Tim peneliti dan kolaborator (pemateri, kepala TK, dan guru non- PG PAUD) melakukan refleksi tentang keseluruhan planning, tindakan dan observasi yang dilakukan selama pelatihan. Setiap orang diberi kesempatan untuk mengungkapkan gagasan, ide, pendapat dan perasaannya, serta membagi pengalaman yang didapatkan dalam melakukan kegiatan pemberdayaan.

Hasil refleksi tersebut adalah sebagai berikut: a) Kegiatan pelatihan pembuatan media pembelajaran PAUD yang dilaksanakan selama dua hari berturut-turut berupa pembuatan media Kotak Huruf dan Angka serta Ular Tangga Pintar yang sebagian besar bahannya dengan memanfaatkan bahan bekas yang mudah didapatkan di lingkungan sekitar TK/PAUD. Pelaksanaan kegiatan pelatihan berlangsung sudah mencapai tujuan sebagaimana yang diharapkan. Peserta pelatihan sudah mulai termotivasi untuk mendesain dan membuat media sendiri dan mengembangkan sesuai kreativitasnya masing-masing. Selain itu peserta pelatihan sudah dapat 
membuat media pembelajaran sebagaimana yang dicontohkan oleh pemateri dan menerapkannya dalam proses pembelajaran di TK/PAUD masing-masing. Berdasarkan hasil refleksi selama kegiatan pelatihan masih ditemukan kelemahan bahwa sebagian besar guru PAUD non PG-PAUD belum memahami secara tepat bagaimana cara mendesain dan membuat media pembelajaran yang mampu mengembangkan aspek-aspek perkembangan anak yang meliputi : aspek nilai-nilai agama dan moral, aspek kognitif, motorik halus dan motorik kasar anak, bahasa dan sosial emosional anak. Kelemahan ini salah satunya disebabkan kurangnya pengetahuan secara teoritis yang dimiliki oleh guru PAUD Non PG-PAUD karena pada dasarnya latar belakang pendidikan guru tersebut bukan dari Pendidikan Guru PAUD. Kemudian dilanjutkan ke Siklus II berupa pelaksanaan implementasi pembuatan media di sekolah masingmasing guru, yang memperlihatkan reaksi positif dari anak-anak didik, ketika observasi refleksi hasil workshop dilakukan oleh peneliti ke tiap-tiap sekolah masing-masing peserta pelatihan.

\section{Pembahasan}

Berdasarkan hasil evaluasi tim peneliti bersama dengan pemateri melalui pengamatan terhadap peserta pelatihan yang telah menggunakan media kotak huruf dan angka serta ular tangga pintar tersebut dalam proses pembelajaran di TK/PAUD tempat mengajar memperlihatkan dari faktor siswa; Siswa lebih aktif dalam mengikuti proses pembelajaran, ,lebih termotivasi dalam mengikuti proses pembelajaran, proses pembelajaran menjadi lebih menarik dan menyenangkan karena melalui penggunaan media Ular Tangga Pintar guru sudah menerapkan prinsip pembelajaran di PAUD yaitu Belajar Melalui Bermain, dan siswa lebih mudah memahami materi yang diajarkan oleh guru melalui penggunaan media ular tangga pintar.

Pada Faktor guru; guru sudah terampil dalam membuat media ular tangga pintar, guru sudah dapat melaksanakan proses pembelaran dengan mengacu pada prinsip belajar melalui bermain, dan guru sudah mampu menggunakan media ular tangga pintar dalam proses pembelajaran secara tepat. Dari kegiatan siklus II, penelitian ini mengambil media kotak huruf sejatinya digunakan dengan huruf dengan berbagai warna sebagai pengenalan literasi awal huruf kapital dan huruf kecil. Pemberian pernak pernik warna yang bervariasi dapat diyakini mengembangkan aspek kognitif dan motorik halus anak. Begitu pula dalam proses pembuatan media kotak angka. Hal ini selaras dengan pendapat yang mengatakan bahwa warna merupakan pesona visual sebagai media tumbuh kembang anak, media komunikasi perasan hati anak, serta media bermain untuk tumbuh kembang buah hati dalam hal ini anak usia dini[16]. Selain itu, penggunaan stik yang dapat dilepas-pasang menjadikan anak menganggapnya sebagai permainan edukatif yang menyenangkan. Sebuah rekomendasi dari penelitian terdahulu, bahwa Kegiatan keaksaraan yang terbaik tersedia dalam konteks yang ber-makna kegiatan yang otentik.denganpermainan yang menyenangkan diharapkan seluruh aspek perkembangan dapat dicapai secara bersama-sama, karena metode bermain dapat menarik anak untuk membaca[17]. Pembuatan media ini menjadikan guru PAUD menyadari akan ketertarikan untuk membuat dan mendesain media pembelajaran yang variatif dan bermakna sebagai pengenalan awal aksara dan angka.

Aktivitas yang menggunakan media hasil worshop membuat anak bermain sambil bergerak dan berpindah. Hal ini melatih anak untuk tidak diam di tempat dan juga sebagai bentuk peningkatan kepercayaan diri anak serta beraktualisasi untuk mengembangkan kecerdasan emosional dan sosial anak. Perkembangan anak untuk 
berpindah memudahkan anak untuk lebih gesit dan tidak kaku di tempat. Media ini sangat berfungsi bagi tumbuh kembang dan aktivitas anak. Anak berkembang seiring dengan bertambahnya usia, merupakan modal dasar bagi perkembangan selanjutnya. Dengan kemampuan gerak yang sederhana tersebut, telah memungkinkan bagi anak untuk melakukan aktivitas fisik yang menuntut kemampuan menjelajahi ruang yang lebih luas.

Gerakan anak seperti berpindah tempat satu ketempat yang lain, dapat menangkap dan memainkan suatu objek serta bermain-main dengan teman sebaya adalah kesempatan melakukan aktivitas yang sangat menentukan perkembangan pola gerak selanjutnya. Hal ini senada dengan pendapat bahwa beberapa karakteristik anak adalah Beberapa karakteristik untuk anak usia dini, adalah sebagai berikut: a) memiliki rasa ingin tahu besar, b) merupakan pribadi yang unik, c) suka berfantasi dan berimajinasi, d) masa paling potensial untuk belajar, e) menunjukan sikap egosentris, f) memiliki rentang daya konsentrasi yang pendek, g) sebagai bagian dari makhluk sosial, dan h). bermain merupakan dunia masa anak-anak[18].

Permainan dengan media ini menjadikan anak-anak memanfaatkan gerakan lokomotornya (Hadi, 2019). Selain itu, masa anak-anak merupakan masa yang sangat baik untuk tumbuh kembang anak sehingga anak-anak membutuhkan waktu yang lebih banyak untuk bergerak dan bermain melalui berbagai kegiatan dan aktivitas gerak. Masa ini juga merupakan masa peka bagi anak sehingga terjadi pematangan fungsi fisik dan psikis sehingga anak siap merespon dan mewujudkan semua tugas-tugas perkembangan yang diharapkan agar muncul pada perilaku seharihari[19].

Faktor guru dan siswa sebagai komponen utama dalam kelas dan keberhasilan pembelajaran yang berlangsung adalah merupakan satu kesatuan dalam kegiatan di tamakn kanak-kanak / PAUD. Pada saat belajar melalui bermain, anak tidak begitu menyadari bahwa segala potensi dan kemampuan anak dan juga secara otomatis guru dalam hal ini saling bersinergi sebab bermain adalah kebutuhan anak. Perlu ditekankan bahwa bermain yang menyenangkan dapat merangsang anak untuk melakukan eksplorasi dengan menggunakan benda-benda yang ada di sekitarnya (happy learning) [19] sehingga, anak dapat menemukan pengetahuan dari benda-benda yang dimainkannya. Dari proses kegiatan yang terlihat, media ular tangga pintar menjadikan anak-anak senang dan guru juga menjadi mudah karena dalam prosesnya terbantukan dengan media yang interaktif dan tepat guna.

Guru menyiapkan perangkat media pembelajaran dalam pembelajaran di kelas dengan membuat kegiatan sendiri yang bervariasi. Guru memilih indikator dan membuat kegiatan sesuai sentra yang akan digunakan pada hari itu. Pembelajaranpun menjadi bervariasi dan guru lebih kreatif menggunakan benda konkret sebagai kegiatan pembelajaran. Media yang dibuat guru disesuaikan dengan tema yang akan dipelajarinya, dan ini sangat menunjang motivasi anak dalam belajar di kelas, karena kemampuan anak usia dini tidak lepas dari tahap perkembangan yang dialaminya serta apa-apa yang menjadi penunjang perkembangannya dalam pengalaman belajarnya.

Berbagai faktor dapat mendukung perkembangannya dengan cara memberikan stimulasi yang sesuai dengan tahapannya. Pada tahap usia anak memasuki TK yaitu usia 4-6 tahun, anak dalam menerima informasi ataupun pembelajaran anak berada di tahapan praoperasional. Tahap praoperasional anak usia dini ditandai dengan anak hanya memfokuskan pada satu variabel dan menyamaratakan berdasarkan pengalaman terbatas[20]. Maka pentingnya pembelajaran menggunakan media konkret pada tahap ini agar anak dapat 
memfokuskan pemahamannya terhadap apa yang anak ingin ketahui [21]. Dalam hal motivasi, Motivasi belajar merupakan suatu salah satu peran penting terhadap keberhasilan pembelajaran itusendiri. Peran ini dapat dilihat dari keaktifan siswa, rasa keingintahuan anak terhadap suatu materi yang disampaikan sehingga anak memfokuskan diri memperhatikan materi hingga anak menemukan apa yang ingin di ketahuinya. Dalam hal ini, pembuatan media dan kreatifitas guru dengan kompetensi pedagogik dan profesional, menjadi sangat penting untuk keberhasilan pendidikan anak usia dini.

\section{KESIMPULAN}

Program ini memerlukan proses yang transformosional berkaitan dengan tujuan jangka panjang berupa kemandirian dan perilaku berkelanjutan (sustainability). Model pemberdayaan terfokus pada pelatihan Pembuatan Media Pembelajaran Bahasa Inggris PAUD. Faktor mendasar yang memerlukan perhatian khusus, seperti : (1). Kualifikasi pendidikan sebagian besar guru PAUD masih tamatan SMA dan sarjana non PG-PAUD. (2). Kompetensi Guru mendesain dan membuat media pembelajaran masih rendah karena kurangnya pengetahuan dan ketrampilan yang dimiliki. Pelatihan pembuatan media dengan pemanfaatan barang bekas telah memberikan kesadaran kritis bagi komunitas dampingan akan pentingnya variasi media pembelajaran dengan prinsip Belajar Melalui Bermain dan mempertimbangkan berbagai aspek perkembangan anak usia dini.

\section{PENGHARGAAN}

Terima kasih penulis ucapkan kepada semua pihak yang terlibat dan membantu terlaksananya penelitian ini. Tidak lupa diucapan terima kasih kepada editor dan reviewer Jurnal Murhum yang sudah memberikan kesempatan sehingga jurnal bisa untuk dipublish/diterbitkan.

\section{REFERENSI}

[1] B. Sani, "Kompetensi Pedagogik, Teori dan Praktik Untuk Peningkatan Kinerja dan Kualitas Guru," Jakarta Kata Pena, 2017.

[2] J. M. Sitepu and M. Nasution, "Kreativitas Pembuatan Media Pembelajaran Big Book Pada Guru-Guru RA Di Kecamatan Medan Maimun," J. Prodikmas Has. Pengabdi. Kpd. Masy., vol. 3, no. 1, 2018.

[3] N. Nurhafizah, "Pelatihan Pembuatan Media Pembelajaran Anak Usia Dini menggunakan Bahan Sisa," Early Child. J. Pendidik., vol. 2, no. 2b, pp. 44-53, 2018.

[4] E. Yafie, T. Iriyanto, L. Gonadi, S. Wahyuni, and P. S. P. G. P. J. KSDP, "Workshop Pembuatan Media Education Berbasis PPT Anak Usia Dini Untuk Guru Se-Kota Malang dan Alumni PGPAUD Universitas Negeri Malang," J. KARINOV, vol. 1, no. 2, 2018.

[5] Gordon. A.M. \& Browne. K. M., Beginning and Beyond, Foundation in Early Childhood Education, 8th Editio. USA: USA: Wadsworth Cengage Learning, 2011.

[6] Rusman, Model-model Pembelajaran dan Pengembangan Profesionalisme Guru. Bandung: Rajawali Press, 2010.

[7] M. Chatib, Sekolahnya manusia: sekolah berbasis multiple intelligences di Indonesia. 
Kaifa, 2009.

[8] D. Dini, "Konsep Dasar Pendidikan Anak Usia Dini," Jakarta: Diknas, 2014.

[9] A. Driscoll and N. G. Nagel, Early childhood education, birth-8: The world of children, families, and educators. Allyn $\backslash \&$ Bacon, 2008.

[10] M. Pidarta, "Landasan Pendidikan Stimulis Ilmu Pendidikan Bercorak Indonesia," Jakarta: Rineka Cipta, 2013.

[11] K. Khadijah, "Pengembangan kognitif anak usia dini," 2016.

[12] J. Mika, Z. Zainuddin, and S. An'nur, "Penerapan Model Pembelajaran Advance Organizer (AO) Untuk Meningkatkan Hasil Belajar Siswa," Berk. Ilm. Pendidik. Fis., vol. 2, no. 3, pp. 222-233, 2014.

[13] L. S. Sari, "Kesiapan Pendidik Paud Dalam Mengajar Anak Usia Dini Di Kota Bandung," J. Ilm. Mimb. Demokr., vol. 18, no. 1, pp. 73-90, 2018, doi: 10.21009/jimd.v18i1.9254.

[14] D. Thoifuri and M. Ag, "Menjadi guru inisiator." Semarang: RaSAIL Media Group, 2008.

[15] N. Shofiyah, C. N. Aulina, and N. Efendi, "Peningkatan Kompetensi Pedagogik Guru PAUD dalam Pembuatan Video Pembelajaran Sains Berbasis Smartphone," Murhum J. Pendidik. Anak Usia Dini, vol. 2, no. 1, pp. 23-33, 2021, doi: 10.37985/murhum.v2i1.29.

[16] Munasiroh, "Arti Spesial Warna bagi Si Kecil," Ruang Guru PAUD, 2020. https://anggunpaud.kemdikbud.go.id/index.php/berita/index/20181115133714/ArtiSpesial-Warna-bagi-Si-Kecil.

[17] L. Hudaya and S. Widayati, "Peningkatan Kemampuan Literasi Melalui Pembelajaran Menggunakan Media Papan Flanel di Kelompok B," Paud Teratai, vol. 4, no. 2, 2015.

[18] S. Aisyah and others, "Perkembangan dan konsep dasar pengembangan anak usia dini," Jakarta Univ. terbuka, 2008.

[19] Y. Nurani, Konsep Dasar Pendidikan Anak Usia Dini. Jakarta: PT Indeks, 2009.

[20] R. E. Izzaty, "Perkembangan Peserta Didik." UNY Press, Yogyakarta, 2008.

[21] M. D. Susanti, "Pemanfaatan Media Pembelajaran Terhadap Motivasi Belajar Anak Tk," J. Pendidik. Anak, vol. 4, no. 2, 2015. 